一論 文—

（日本化学会誌，1985，（9)，p. 1639 1643）

(C) 1985 The Chemical Society of Japan

\title{
核磁気共鳴によるフラビンモノヌクレオチドと 銅クロロフィリンの相互作用
}

(1985 年 3 月 16 日受理)

円满字公 衛

\begin{abstract}
銅クロロフィリン $(\mathrm{Cu}-\mathrm{chln})$ とフラビンモノヌクレオチド (FMN) との複合体の分子構造を ${ }^{\mathrm{I}} \mathrm{H}-$, ${ }^{13} \mathrm{C}-$, ${ }^{31} \mathrm{P}-\mathrm{NMR}$ 法により推定した。FMN における内部運動の有無を推定する手段として FMN 単体 の ${ }^{18} \mathrm{C}$-緩和時間を測定した。リボース炭素のみかけの回転相関時間はイソアロキサシン環の孷素に帰 着するそれよりもわずかばかり短く, リボース鎖はいくぶん内部運動している。メチル基は $4 \times 10^{-11} \mathrm{~s}$ の相関時間で内部回転している。 ${ }^{1} \mathrm{H}$-絽緩和時間のデータから, Cu-chln と FMN の複合体の回転相関 時間はすべてのプロトンについて同一の值をもつので，この值を ${ }^{13} \mathrm{C}-\mathrm{NMR}$ のデータの解析に用いた。

$\mathrm{Cu}-\mathrm{chln}-\mathrm{FMN}$ 複合体の FMN 炭素の縦緩和時間を測定した。観測した ${ }^{18} \mathrm{C}-T_{1}$ を仮定した構造か ら推定した $T_{1}$ と比較して複合体の構造を決定するコンピューターシミュレーションを行なった。この 方法において, Cu-chln のクロリン環と FMN のイソアロキサシン環の間の角を $0^{\circ}$ から $90^{\circ}$ まで变 えたところすべての角が可能であった。しかし分光データはクロリン環がイソアロキサシン環と平行で あることを示唆した。その結果, 環一環距離は $4.0 \AA$ であると推定された。 ${ }^{1} \mathrm{H}-\mathrm{NMR}$ の横縟和時間を 使って電子スピンが $\mathrm{Cu}-\mathrm{chln}$ の $\mathrm{Cu}^{2+}$ から FMN プロトンに流入していることを確認した。このこ とは電荷移動錹体が $\mathrm{Cu}-\mathrm{chln}$ と FMN の間に形成されていることを示唆する。
\end{abstract}

\section{1 緒 言}

クロロフィルと電子受容体の相互作用の研究は光合成の初期過 程の研究に対して一つの大きな指標を与えるものである1)。Tsu と Wang はクロロフィルa とフラビンモノヌクレオチド(以下 FMN と略記する) と相互の間の作用を光吸収スペクトルと ESR を用いて研究した2)。彼らは光によって誘導されるクロロフィル aから FMN に向けての電子の移行を発見した。さらに著者は クロロフィルa と F MN の複合体の構造を推定する一方法とし て，銅クロロフィリン（以下 $\mathrm{Cu}-\mathrm{chln}$ と略記する）と FMN の 複合体の構造を研究した ${ }^{3)}$ 。Cu-Chln は $\mathrm{Cu}^{2+}$ の常磁性効果によ り FMN のブロトンとリンの䋊緩和時間 $\left(T_{1}\right)$ に影響をおよぼ していた。しかしながら，FMN の NMR 钼測可能なプロトン は $\mathrm{C}(6) \sim \mathrm{C}(9)$ を含む環にのみ局在しているので, ${ }^{1} \mathrm{H}-\mathrm{NMR}$ のみの研究から複合体の構造を議論するのは困難であった ${ }^{8)} 。$

この研究は FMN の ${ }^{13} \mathrm{C}-\mathrm{NMR}$ の $T_{1}$ におよぼす $\mathrm{Cu}-\mathrm{ch} / \mathrm{n}$ の効果について述べたものである。炭素は FMN の分子全体に 分布しているので ${ }^{13} \mathrm{C}-T_{1}$ から得られる情報量が ${ }^{1} \mathrm{H}-$ の場合よ り多く, ${ }^{1} \mathrm{H}-\mathrm{HMR}$ のような問題は生じない。 $\mathrm{Cu}-\mathrm{chln}$ の $\mathrm{Cu}^{2+}$ 京都大学理学部化学教室, 606 京都市左京区北白川追分 町

** 現在 三菱電機株式会社材料研究所, 661 尼崎市塚口本町

1) 加藤 栄, 化学の領域, 36, 61(1982).

2) S. Tsu, J.H.Wang, Biochem. Biophys. Res. Commun., 36, 79(1969).

3) K. Enmanji, Bull. Chem. Soc. Jpn., 52, 1275(1979).
と FMN の炭素との間のみかけの臣離を複合体の ${ }^{18} \mathrm{C}-T_{1}$ から 求め, 複合体の構造を計算機シミュレーションにより推定した。 また複合体の ${ }^{1} \mathrm{H}$-綎および横叞和時間のデータを解析じて部合 体の回転相関時間を决定した。さらK Cu-chln から FMN ブロ トンへの電子のしみだしを見いだしたので報告する。

\section{2 実}

2.1 材 料

$\mathrm{Cu}-\mathrm{chln}$ と Mg-chln は既報の方法で得た。特酸の FMN は 半井化学から入手し，精製せずに用いた。

\subsection{NMR 測定}

${ }^{1} \mathrm{H}$ - および ${ }^{1} \mathrm{H}$-をデカップルした ${ }^{15} \mathrm{C}-\mathrm{NMR}$ スペクトルはハ ルス Fourier 変換装固 (PFT-100) および EC-100 スべりトル コンピューターを装着した日本電子製 PS-100 高分解能 NMR

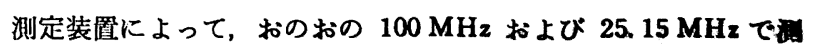
定した。T $T_{1}$ は $180^{\circ}-\tau-90^{\circ}$ バルス法によって娜定した。

差スペクトルは Cu-chln と FMN の混合商液の入った七ル および緩衝液の入ったセルを試料側に，Cu-chln 容波の入った セルおよびFMN 满の入ったセルを参照側において島津MPS5000 自記分光光度計で測定した。

\section{3 結果と考腺}

\section{1 水溶液中ての FMN の正较状意}

水溶液中での FMN の運動状態を調べるため, $30^{\circ} \mathrm{C} て 1 \mathrm{~mol} \cdot$ $\mathrm{dm}^{-3}$ FMN 重水溶液 (pH 7.5) の ${ }^{13} \mathrm{C}-\mathrm{NMR}$ の $T_{1}$ を河定し 
Table 1 Carbon relaxation rates of flavine mononucleotide at $30^{\circ} \mathrm{C}$

\begin{tabular}{|c|c|c|c|c|}
\hline $\begin{array}{c}\text { Carbon } \\
\text { No. }\end{array}$ & $\begin{array}{l}T_{1^{-1}} \\
\left(\mathrm{~s}^{-1}\right)\end{array}$ & $\begin{array}{c}\left(N T_{1}{ }^{o}\right)^{-1} \\
\left(\mathrm{~s}^{-1}\right)\end{array}$ & $\begin{array}{l}\tau_{\mathrm{C}^{\text {efr }}} \\
\text { (ns) }\end{array}$ & $\underset{(\mathrm{ns})^{-1}}{R_{\mathrm{nt}}}$ \\
\hline$C(2)$ & 1.0 & & & \\
\hline$C(4)$ & 0.9 & & & \\
\hline$C(6)$ & 17.2 & 17.2 & 0.75 & \\
\hline$C(7,8)$ & 0.9 & & & \\
\hline$C(9)$ & 17.6 & 17.6 & 0.77 & \\
\hline$C(9 a)$ & 1.0 & & & \\
\hline$C(5 a)$ & 1.2 & & & \\
\hline$C(10 a)$ & 1.4 & & & \\
\hline$C(4 a)$ & 0.9 & & & \\
\hline$C\left(1^{\prime}\right)$ & 37.7 & 18.9 & 0.73 & \\
\hline$C\left(2^{\prime}\right)$ & 18.8 & 18.8 & 0.70 & \\
\hline$C\left(3^{\prime}\right)$ & 16.6 & 16.6 & 0.73 & \\
\hline$C\left(4^{\prime}\right)$ & 16. 5 & 16.5 & 0.70 & \\
\hline C ( $\left.5^{\prime}\right)$ & 23. 5 & 12.0 & 0.45 & \\
\hline$C(7 a)$ & 3.1 & 1.0 & 0.05 & 25 \\
\hline$C(8 a)$ & 3.4 & 1.1 & 0.05 & 25 \\
\hline
\end{tabular}

a) $T_{1}{ }^{\circ}$ is the longitudinal relaxation time in the absence of copper chlorophyllin. Flavine mononucleotide ; $1 \mathrm{~mol} / l$.

b) $N$ denotes the number of protons attached to carbon.

た。各炭来の $T_{1}$ を表 1 に示す。このとき，プロトンの結合して いる炭秦は直接結合しているプロトンとの 双極子-双極子相互作 用によって瑷和し，極度尖鋭化の条件下 $\left(\tau_{0}<8.1 \times 10^{-9} \mathrm{~s}\right)$ では $1 / T_{1}$ は式(1)で表わすことができるい。

$$
\frac{1}{T_{1}}=\frac{\hbar^{2} r_{\mathrm{H}}^{2} \gamma_{\mathrm{C}}^{2}}{\left(r_{\mathrm{C}-\mathrm{H}}\right)^{8}} \tau_{\mathrm{C}}^{\mathrm{erP}}
$$

ここで $\tau_{0}^{\text {ofr }}$ は有効相関時間である。各炭素の $\tau_{\mathrm{o}}^{\mathrm{eff}}$ を求めて結 果を表1反示した。 $\boldsymbol{r}_{\mathrm{C}-\mathrm{H}}$ はリボフラビンの $\mathrm{X}$ 線解析からの值を 使った")。表 1から、イソアロキサジン環の炭素 (C（6) と C (9)) は毦同し $\tau_{0}$ off $\left(7.5 \times 10^{-10} \mathrm{~s}\right.$ と $\left.7.7 \times 10^{-10} \mathrm{~s}\right)$ をすっ ているのに対して, メチル基の炭素 (C(7a) と C (8a))の $\tau_{\mathrm{O}}{ }^{\text {eff }}$

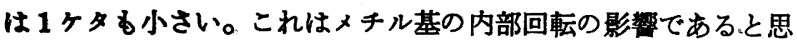
われるので, Woessner の理論で解析を試みたの)。

$$
\frac{1}{T_{1}}=\frac{3 r_{\mathrm{H}}^{2} \gamma_{\mathrm{C}^{2} \hbar^{2}}}{\left(r_{\mathrm{O}-\mathrm{H}}\right)^{2}}\left[\frac{A}{6 R}+\frac{B+C}{6 R+R_{\mathrm{Int}}}\right]
$$

ここで, $R$ は分子全体の回転運動の拡散定数で，式(1)から $R=$ $\left.1 / 6 \tau_{0}^{\text {off }} \mathrm{C}(6), \mathrm{C}(9)\right)$ の関俰から C (6), C (9) の $T_{1}$ の 值を用いて計算して得られる。 $R_{\mathrm{lnt}}$ は同様に， 3 部位跳躍を仮定 したときのょチル基の内部運動の拡散定数である。また， $A, B$, $C$ は承何学的因子で式 (3)，(4)，(5)で与えられる7)。

$$
A=\frac{1}{4}\left(3 \cos ^{2} \Delta-1\right)^{2}
$$

4) N. Bloembergen, E. M. Purcell, R. M. Pound, Phys. Rev., 73, 677(1948).

5) N. Tanaka, T. Ashida, Y.Sasada, Bull. Chem. Soc. Jpn., 42, 1546(1969).

6) H. Beierbeck, R. Martino, J.K. Saunders, Can. J. Chem., 58, 102(1980).

7) D. E. Woessner, J. Chem. Phys., 36, 1(1962).

$$
\begin{aligned}
& B=\frac{3}{4} \sin ^{2} 2 \Delta \\
& C=\frac{3}{4} \sin ^{4} \Delta
\end{aligned}
$$

ここで, ムは核と核ではるべクトルと回転蟿との間の角であ る。

式(2)と表1からえられた結果を表1に併記した。FMNメチ ル基の $R_{\mathrm{Int}}$ の值は 1-メチルナフタレンのメチル基の $R_{\mathrm{lnt}}(4.0$ $\left.\times 10^{11} \mathrm{~s}^{-1}\right)$ とくらべて 1 ケタ小さい ${ }^{8)}$ 。さらにリボースの炭素の $\tau_{\mathrm{O}}{ }^{\text {orf }}$ はリボース鎖の回耺の自由度にしたがって順に小さくなっ ているが，C(1')から C(4') まではインアロキサジンの炭素 ( C (9), C (6))の $\tau_{\mathrm{C}}^{\text {eff }}$ とほとんどかわらず，リボース鎖中に いくぶんかの内部運動が存在することを示唆している。

$3.2 \mathrm{Cu}-\mathrm{chln}-\mathrm{FMN}$ 複合体のプロトンおよびリンの縰および 横楥和時間の解析

図 1 に Cu-chln-FMN 複合体の ${ }^{1} \mathrm{H}-$ および ${ }^{31} \mathrm{P}-の f T_{1 \mathrm{p}}$, $f T_{2 \mathrm{p}}$ の温度変化を既報8で求めた ${ }^{31} \mathrm{P}-$ に対する值とともに示 す。ここで $T_{\imath \mathrm{p}}(i=1,2)$ は真の緩和時間 $T_{\text {似 }}$ と式 $(6)$ によっ て関係づけられるき。

$$
\frac{2}{\Delta T_{i_{\mathrm{p}}}}=\frac{1}{T_{i}{ }^{*}}-\frac{1}{T_{i}{ }^{0}}=\frac{f}{T_{i_{\mathrm{M}}}+\tau_{\mathrm{M}}}(i=1,2)
$$

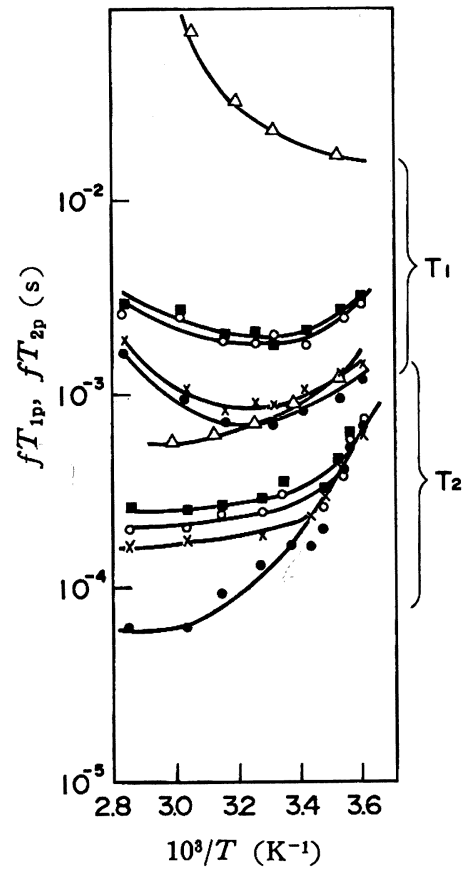

Fig. 1 Temperature dependency of $f T_{1 \mathrm{p}}$ and $f T_{2 \mathrm{p}}$ for the copper chlorophyllin-flavine mononucleotide complex in ${ }^{1} \mathrm{H}-$, ${ }^{31} \mathrm{P}-\mathrm{NMR}$

The values of $f T_{1 \mathrm{p}}$ were determined previouslys) -O- : C (9) H, - $\times-: \mathrm{C}(6) \mathrm{H},-\mathrm{O}-: \mathrm{C}(8)$. $\mathrm{CH}_{3},-\square-: \mathrm{C}(7) \mathrm{CH}_{3},-\triangle-: \mathrm{P}$

8) A. Ericsson, J. Kowalewski, Chem. Phys., 60, 387 (1981).

9) T. J. Swift, R. E. Connick, J. Chem. Phys., 37, 307 (1962). 
$T_{\imath}{ }^{*}$ は Cu-chln が存在しているときの $T_{\imath}, T_{\imath}{ }^{0}$ は $\mathrm{Cu}-\mathrm{chln}$ が存在していないときの $T_{\imath}, f$ は $\mathrm{Cu}-\mathrm{chln}$ と FMNのモル比, $\tau_{\mathrm{M}}$ は複合体の存在寿命である。因 1 から $17 \mathrm{C}$ までは $\mathrm{C}(9) \mathrm{H}$, $\mathrm{C}$ ( 6 ) $\mathrm{H}, \mathrm{C}(8) \mathrm{CH}_{3}, \mathrm{C}(7) \mathrm{CH}_{3}$ ともほぼ同一の $f T_{2 \mathrm{p}}$ の值 をとり，温度に対する挙動から，この領域では $T_{2 \mathrm{p}}$ は $\tau_{\mathrm{M}}$ に支配 されていることがわかる。このとき直線の傾さから複合体の解離 速度に対する活性化エンタルピーが $42 \mathrm{~kJ} / \mathrm{mol}$ と計算された。 $23.5^{\circ} \mathrm{C}$ に打ける結合定数 $(330 l / \mathrm{mol}) と k_{-1}=\tau_{\mathrm{M}}{ }^{-1}\left(0.63 \times 10^{4}\right.$ $\left.\mathrm{s}^{-1}\right)$ とから, $k_{+1}$ が $2.1 \times 10^{8} \mathrm{~s}^{-1} \cdot l \cdot \mathrm{mol}^{-1}$ と計算された。温度が 上昇すると， $\mathrm{C}(9) \mathrm{H}$ の $f T_{2 \mathrm{p}}$ は $55^{\circ} \mathrm{C}$ まで $\tau_{\mathrm{M}}$ と同じ勾配で 減少し， $\mathrm{C}(6) \mathrm{H}, \mathrm{C}(8) \mathrm{CH}_{3}, \mathrm{C}(7) \mathrm{CH}_{3}, \mathrm{P}$ の $f T_{2 \mathrm{p}}$ はそれ よりもはるかにゆるい勾配で減少した。この結果から, C (9) H の $T_{2 \mathrm{p}}$ は $55^{\circ} \mathrm{C}$ までは $\tau_{\mathrm{M}}$ で支配され, $\mathrm{C}(6) \mathrm{H}, \mathrm{C}(8) \mathrm{CH}_{3}$, $\mathrm{C}$ (7) $\mathrm{CH}_{3} ， \mathrm{P}$ では $T_{2 \mathrm{M}}$ で支配されると考光られる。 $T_{1 \mathrm{M}}, T_{2 \mathrm{M}}$ はおすに電子スピンとの双極子相互作用によると思われるので， 等方的な回転の仮定の下ではつぎの Solomonの式が成り立つ ${ }^{10) 。}$

$$
\begin{aligned}
& \frac{1}{T_{1 \mathrm{M}}}=\frac{2}{15} S(S+1) \frac{r_{\mathrm{I}}^{2} g^{2} \beta^{2}}{r^{6}}\left[\frac{3 \tau_{\mathrm{C}}}{1+\omega_{\mathrm{I}}^{2} \tau_{\mathrm{C}}^{2}}\right] \\
& \frac{1}{T_{2 \mathrm{M}}}=\frac{1}{15} S(S+1) \frac{\gamma_{\mathrm{I}}^{2} g^{2} \beta^{2}}{r^{6}}\left[4 \tau_{\mathrm{O}}+\frac{3 \tau_{\mathrm{C}}}{1+\omega_{\mathrm{I}}{ }^{2} \tau_{\mathrm{C}}{ }^{2}}\right] \\
& +\frac{1}{3}\left(\frac{A}{\hbar}\right)^{2} S(S+1) \tau_{\mathrm{o}} \\
& \tau_{\mathrm{C}}^{-1}=\tau_{\mathrm{r}}^{-1}+\tau_{\mathrm{M}}^{-1}+T_{1 \mathrm{e}}^{-1} \\
& \tau_{\mathrm{e}}^{-1}=\tau_{\mathrm{M}}^{-1}+T_{1 \theta}^{-1}
\end{aligned}
$$

ここで，Sは電子のスピン量子数， $\beta$ は電子の Bohr 磁子， $\boldsymbol{r}$ は 電子スピンと核スピン間の距離， $A$ は超微細分裂定数， $\tau_{\mathrm{M}}$ は複 合体の寿命, $T_{1 \mathrm{e}}$ は電子緩和時間， $\tau_{\mathrm{e}}$ は電子相関時間である。 $\mathrm{C}(6) \mathrm{H}, \mathrm{C}$ ( 8) $\mathrm{CH}_{3}, \mathrm{C}(7) \mathrm{CH}_{3}, \mathrm{P}$ の $f T_{2 \mathrm{p}}$ が $17^{\circ} \mathrm{C}$ 以上で 温度に対し負の勾配をむつ $80^{\circ} \mathrm{C}$ 付近でも $f T_{1 \mathrm{p}}$ と $f T_{2 \mathrm{p}}$ に大き な差があり， $f T_{2 \mathrm{p}}$ の温度变化が緩やかで各プロトンによりその 值が異なっていることは，fT $T_{2 \mathrm{p}}$ が (8)式の第1項（双極子相互 作用）ではなく第 2 項（スカラー相互作用）に支配されており， かつ $\tau_{\theta}$ が $T_{10}$ に支配されているからであると考えられる。（7） 式を使って $T_{1 \mathrm{M}}$ の最小值と各温度に批る $T_{1 \mathrm{M}}$ の值の比から, 各温度における $\mathrm{Cu}-\mathrm{chln}-\mathrm{FMN}$ 複合体の回転相関時間 $\tau_{\mathrm{c}}$ を求 めて ${ }^{11)}$ ，図 2 に示した。眓 2 の直線の傾きから、 $\tau_{\mathrm{O}}$ の活性化エ ネルギーを $27.8 \mathrm{~kJ} / \mathrm{mol}$ と決定した。 $\tau_{\mathrm{C}}$ の活性化ェネルギーは 複合体の回転障壁を示するのであり, FMN 単体の $\tau_{\mathrm{C}}$ 活性化エ ネルギー $23 \mathrm{~kJ} / \mathrm{mol}^{12)}$ とくらべて少し大きくなっており, 複合 体の方が FMN 二量体より少し回転障壁が大きいことを示す。

\section{$3.3{ }^{13} \mathbf{C}-\boldsymbol{T}_{1 \mathrm{p}}$ の測定と $\boldsymbol{f}$ の決定}

$30^{\circ} \mathrm{C}$ で $\mathrm{Cu}-\mathrm{chln}\left(<25 \mathrm{mmol} \cdot \mathrm{dm}^{-3}\right)$ を FMN ( $1 \mathrm{~mol} \cdot \mathrm{dm}^{-3}$, $\mathrm{pH}$ 7.5) に添加すると $\mathrm{Cu}-\mathrm{chln}$ の添加量に比例して FMN の すべての炭素環の緩和速度が增大寸る (因 3 参照)。複合体形成 による $\tau_{\mathrm{C}}$ の変化をみつもるために $\mathrm{Mg}-\mathrm{chln}$ を FMN 溶液に 加之た。 $20 \mathrm{mmol} \cdot \mathrm{dm}^{-3} \mathrm{Mg}$-chln を $1 \mathrm{~mol} \cdot \mathrm{dm}^{-3} \mathrm{FMN}$ 溶液に 加えてもFMN 炭素の緩和速度は增加しなかった。これは， $\mathrm{Mg}$

10) L. Solomon, Phys. Rev., 99, 559(1955).

11) A. Yamada, K. Akasaka, H. Hatano, Biopolymers, 15 , 1315(1976)

12）円満字公衛, 未発表データ.

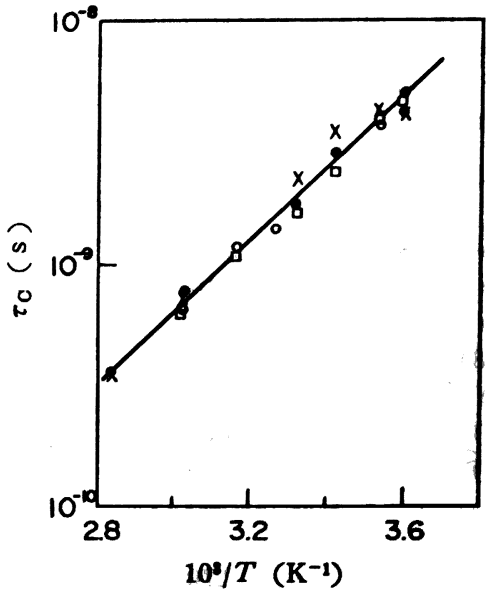

Fig. 2 Temperature dependency of $\tau_{0}$ for the copper chlorophyllin-flavine mononucleotide complex
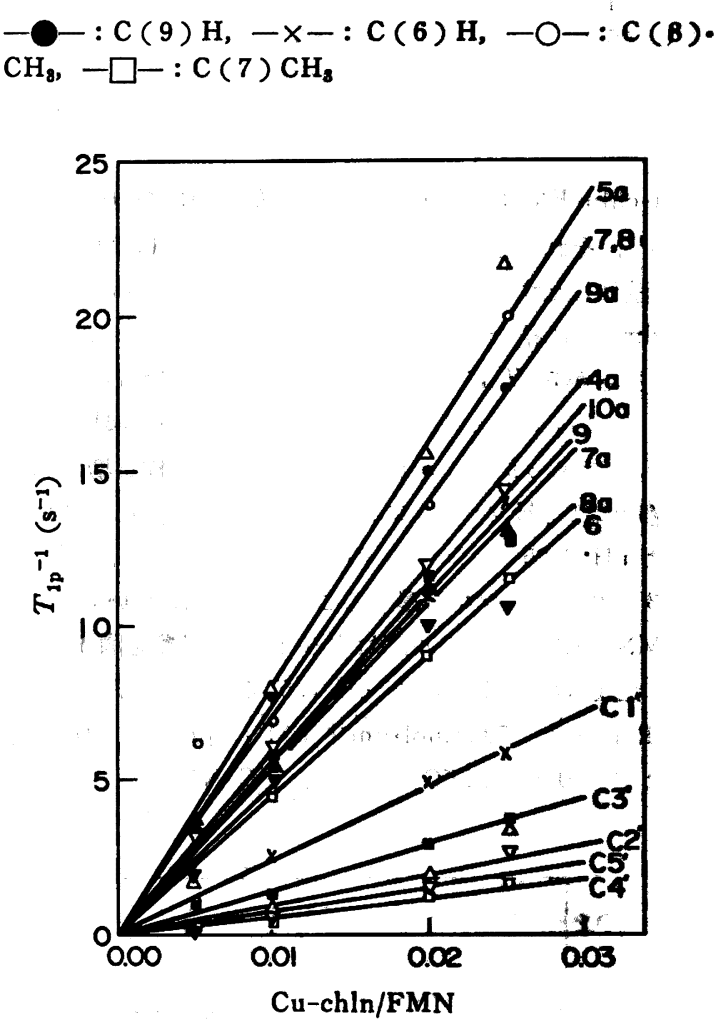

Fig. 3 Effect of added copper chlorophyllin on the ${ }^{19} \mathrm{C}$ $T_{1 \mathrm{p}}{ }^{-1}$ of flavine mononucleotide

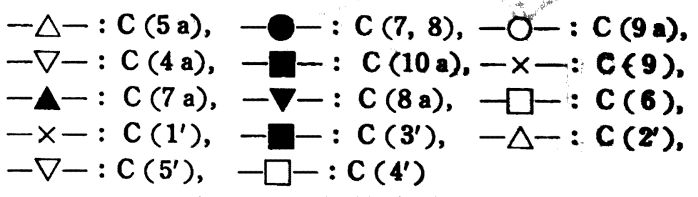

$\operatorname{chln}(f=0.02$ 程度) を加えてる粘度の增加はないことを示す。 測定された ${ }^{13} \mathrm{C}-T_{1} に$ 含まれる諆差とフランタション比から时算 すると, FMN と Mg-chln の落合体形成に上る なく，その上限は約 2 倍であることがわかった。著者の以前の得

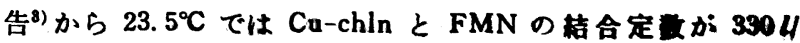
$\mathrm{mol}^{3)}$ で結合数は1であることがわかっている。低泪 ESR 四定 
Table $2 T_{1 \mathrm{M}}{ }^{-1}$ and Apparent distances between electronic spins and carbons in the copper chlorophyllin-favine mononucleotide complex

\begin{tabular}{|c|c|c|}
\hline Carbon No. & $\begin{array}{l}T_{1 \mathrm{M}^{-1}} \\
\left(\mathrm{~s}^{-1}\right)\end{array}$ & $\begin{array}{l}r^{\mathrm{app}} \\
(\AA)\end{array}$ \\
\hline C (2) & 255 & 5.4 \\
\hline C (4) & 310 & 5. 4 \\
\hline C (6) & 450 & 5.1 \\
\hline C $(7,8)$ & 475 & 4. 7 \\
\hline C (9) & 555 & 4. 9 \\
\hline C (9a) & 670 & 4. 7 \\
\hline$C(5 a)$ & 780 & 4. 7 \\
\hline$C(10 a)$ & 590 & 4.9 \\
\hline$C(4 a)$ & 605 & 4.8 \\
\hline $\mathrm{C}\left(1^{\prime}\right)$ & 270 & 5. 6 \\
\hline $\mathrm{C}\left(2^{\prime}\right)$ & 115 & 6.5 \\
\hline$C\left(3^{\prime}\right)$ & 150 & 6.1 \\
\hline $\mathrm{C}\left(4^{\prime}\right)$ & 85 & 6.7 \\
\hline C $\left(5^{\prime}\right)$ & 95 & 6.6 \\
\hline C $(7 \mathrm{a})$ & 580 & 4. 9 \\
\hline$C(8 a)$ & 525 & 5.0 \\
\hline
\end{tabular}

から Cu-chln-FMN 複合体に执いて, Cu-chln 同士には相互作 用はない8)。それゆえ $1: 1$ 複合体のみを考えればよい。結合定 数から, 添加したすべての Cu-chln (<25 mmol· $\left.\mathrm{dm}^{-3}\right)$ は FMN $\left(1 \mathrm{~mol} \cdot \mathrm{dm}^{-8}\right)$ に結合していると判断される。それゆえ， $f$ と $T_{1 \mathrm{p}}{ }^{-1}$ の積とから $T_{1 \mathrm{M}}^{-1}$ が求められる。 $30^{\circ} \mathrm{C}$ に打ける $\tau_{\mathrm{C}}=1.6$ $\times 10^{-9} \mathrm{~s}$ と $T_{1 \mathrm{M}}$ の值から $r^{\mathrm{app}}$ を求めた (表 2 )。 $\mathrm{pH}$ が ${ }^{1} \mathrm{H}$-测 定時は 5.8 であったのに対して, FMN の溶解性を増すために, ${ }^{18} \mathrm{C}$-測定時には $\mathrm{pH}$ を 7.5 にたもった。 $\mathrm{pH}$ を変化させたとき， FMN は pH 0.25 で N (1) のプロトンを解離し, $\mathrm{pH} 10.25$ でN (3) のプロトンを解離することが知られている ${ }^{13)}$ 。 $\mathrm{Cu}-$ chln-FMN の差スペクトルに対する $\mathrm{pH}$ の影響を図 4 に示す。 図で示したように $\mathrm{pH} 5.8$ と $\mathrm{pH}$ 7.5 で差はみられなかった。 ${ }^{1} \mathrm{H}-\mathrm{NMR}$ により, $70 \mathrm{mmol} \cdot \mathrm{dm}^{-3} \mathrm{FMN}(\mathrm{pH} \mathrm{5.8)}$ の $\mathrm{C}(6) \mathrm{H}$ の $\tau_{\mathrm{c}}$ は $8 \times 10^{-10} \mathrm{~s}\left(25^{\circ} \mathrm{C}\right)$ であり, ${ }^{13} \mathrm{C}-\mathrm{NMR}$ よりの $1 \mathrm{~mol} ・$

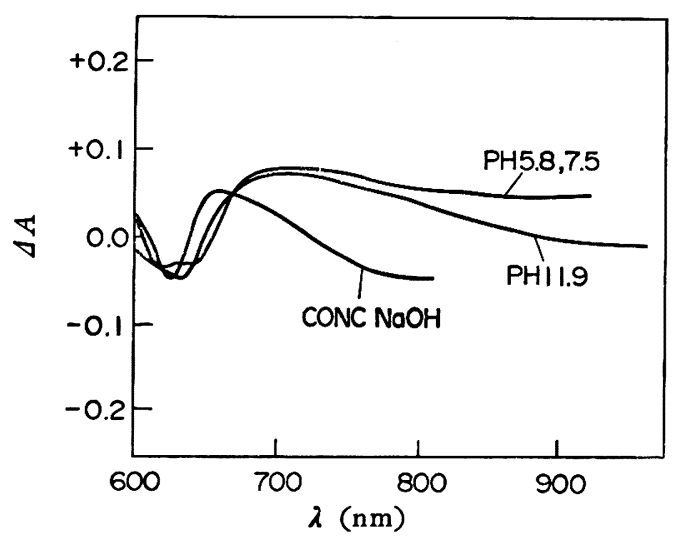

Fig. $4 \mathrm{pH}$ Dependency of the difference spectrum for the copper chlorophyllin-flavine mononucleotide complex

13) E. J. Land, A. J. Swallow, Biochemistry, 8, 2117 (1969). $\mathrm{dm}^{-3} \mathrm{FMN}(\mathrm{pH} \mathrm{7.5})$ の $\mathrm{C}(9), \mathrm{C}(6)$ の $\tau_{\mathrm{C}}\left(7.5 \times 10^{-10} \mathrm{~s}\right.$, $\left.30^{\circ} \mathrm{C}\right)$ と変らなかった ${ }^{12)}$ 。以上のことから ${ }^{1} \mathrm{H}-$ と ${ }^{13} \mathrm{C}-\mathrm{NMR} の$

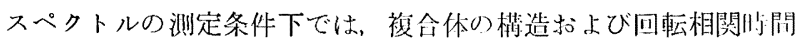
はほとんど变化がないものと考えられる。

\section{4 計算機による複合体の構造決定 ${ }^{14)}$}

$\mathrm{Cu}-\mathrm{chln}$ のクロリン愣と FMN のイソアロキサジン環の原子 夾䧣を文献 15）と文润 5）のようにとり，Cu-chln の中心を原 点にとってイソアロキサジン環の中心座標を $(x, y, z)$, イソア ロキサジン環のクロリン環に対する傾きを( $\theta)$, 中心夾標に执い て面に垂直にたてた軸と $x$ 軸の角度を( $(\phi)$, イソアロキサジン環 の中心軸のまわりの回転角を( $\psi$ 多として, $x, y, z$ は $1 \AA$ ごと, $\theta, \phi, \phi$ は $30^{\circ}$ ごとに変化して $\mathrm{Cu}-\mathrm{chln} \sigma \mathrm{Cu}^{2+}$ イオンおよびN 原子と FMN の各炭素との距離を計算した。ここで不対電子は $\mathrm{Cu}$-chln-FMN 複合体の低温 ESR スペクトルより Roberts と Koski の手法 ${ }^{16) を}$ を使って計算した結果, $\mathrm{Cu}^{2+} に 65 \%$, ピロール のN原子に $8.8 \%$ ずつ局在しているとした。つぎに複合体の $T_{1 \mathrm{M}}$ を式( 7 )を使って求めた。

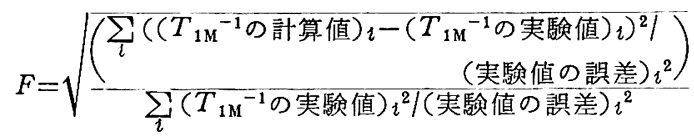

式 (11) で定義した $F$ が最小となるよらに計算を実行した。これ らの計算についての明解な解はなく，Fの值の比較的小さい值

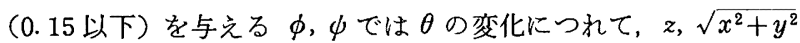
が図5のよらに変化することがわかった。 $\theta=40^{\circ} \sim 90^{\circ}$ の構造は 立体障害のため可能性がない。さらに Cu-chln-FMN の差スペ クトルは尿素添加で変化しないことから， Cu-chln は FMN と 水素結合していないと思われる。クロロフィル の電子移動が困難であることも考虑すると $\theta=20^{\circ} \sim 30^{\circ}$ の構造は 考えにくい。それゆ光，図6には $\theta=0^{\circ}$ としたとさの構造を代表 として示した。このときの $\mathrm{Cu}$-chln-FMN 複合体の中心間距離 (z) は $4.0 \AA(F=0.12)$ であり, ${ }^{1} \mathrm{H}-\mathrm{NMR}$ からの結諭とよく 一致している。表 2 と図 6 から, リボースの炭素はイソアロキサ

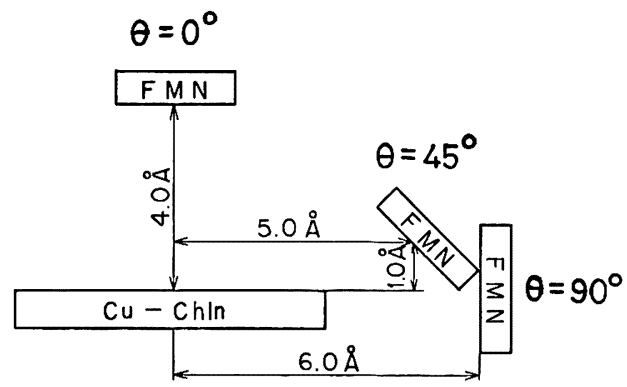

Fig. 5 Possible configurations between $\mathrm{Cu}$-chln (larger rectangles) and FMN (smaller rectangle, viewed from one end of the long axis) as a function of the interplanar angle $\theta$

14) Y. Nosaka, K. Akasaka, H. Hatano, J. Am. Chem. Soc., 100, 706(1978).

15) C. J. Brown, J. Chem. Soc. A, 1968, 2488.

16) E. M. Roberts, W.S. Koski, J. Am. Chem. Soc., 82, 3006(1969). 


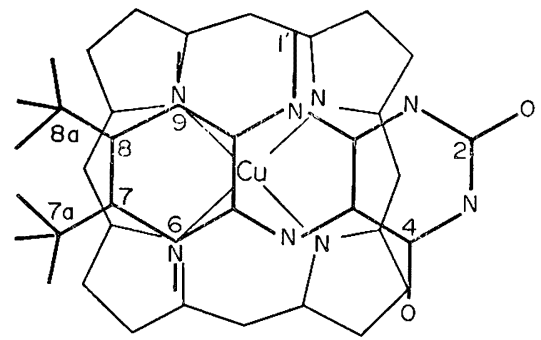

Fig. 6 Time most probable structure of the $\mathrm{Cu}-\mathrm{chln}-$ FMN complex

ジン瓄の炭素よりも電子スピンから離れており, 複合体形成によ る相互作用は C (1') から C ( $\left.4^{\prime}\right)$ までは炭素番号が增すにした がって弱くなっている。またメチル基の存在する蹯水部のほうが カルボニル基の存在する親水部よりも強く相互作用している。す なわち，Cu-chln とイソアロキサジン環との相互作用の性質は
親水的といらよりも疎水的である。

図1のリンの $f T_{1 \mathrm{p}}$ の最小值と $\tau_{\mathrm{C}}=3.98 \times 10^{-9} \mathrm{~s}$ を使って計 算するとリンと電子スピンの間は $8.0 \AA$ 離れていることがわか る。FMN の結晶構造から考察すると $\mathrm{Cu}-\mathrm{chln}$ のカルボキシル 基は $\mathrm{Cu}^{2+}$ から $7 \AA$ 離れて打り，このカルボキシル基とリン酸 基の0が $2 \AA$ 離れて水へ結合しているとすると, $\mathrm{Cu}^{2+}$ と $\mathrm{P}$ 間は $8 \AA$ 程度になり,つじつまがあう。

これらのことから, Cu-chln と FMN の複合体は 1,7-ナフタ レンジオールとフラビンの複合体 ${ }^{17)}$ と同様にクロリン環とイソア ロキサジン環が重なりあって電荷移動しやすい形になっているも のと考えられる。また，電子スピンが FMN のプロトンにしみ だしていることは Cu-chln-FMN 複合体が電荷移動錯体である ことを值接示唆するものである。

17) C. A. Langhoff, C. J. Fritchie, Jr., Chem. Comm., 1970, 702.

\title{
Interaction between Flavine Mononucleotide and Copper Chlorophyllin Studied by Nuclear Magnetic Resonance
}

\author{
Koe Enmanji \\ Department of Chemistry, Faculty of Science, Kyoto University ; Kitashirakawa, \\ Sakyo-ku, Kyoto-shi 606 Japan \\ ** Present Address : The Materials Engineering Laboratory of Mitsubishi Electric \\ Corp.; Tsukaguchi-Honmachi, Amagasaki-shi 661 Japan
}

The molecular structure of the complex between copper chlorophyllin $(\mathrm{Cu}-\mathrm{chln})$ and flavine mononucleotide (FMN) was investigated by ${ }^{1} \mathrm{H}-,{ }^{13} \mathrm{C}-$, and ${ }^{31} \mathrm{P}-$ relaxation times for $\mathrm{FMN}$ alone were measured first in order to examine the rigidity and internal motion of FMN. The apparent rotational correlation times of ribose carbons are slightly shorter than those of the carbons on the isoalloxazine ring; this suggests the existence of some degree of internal motion in the ribose chain. The methyl groups showed internal rotation with a correlation time of $4 \times 10^{-11} \mathrm{~s}$.

The ${ }^{13} \mathrm{C}-T_{1}{ }^{\prime} \mathrm{s}$ for $\mathrm{FMN}$ in the $\mathrm{Cu}-\mathrm{chln}-\mathrm{FMN}$ complex were measured at $30^{\circ} \mathrm{C}$. Computer simulation was applied to determine the probable structure of the complex. The rotational correlation time neccesary in this simulation was esimated from ${ }^{1} \mathrm{H}-T_{1}$ data. The angle between the $\mathrm{Cu}$-chln chlorin ring and the $\mathrm{FMN}$ isoalloxazine ring was varied from $0^{\circ}$ to $90^{\circ}$ and each angle gave a reasonable fit of the calculated $T_{1}$ 's with those determined experimentally. For a parallel configulation of the two rings, suggested by optical data, the ring-ring distance was determined from the ${ }^{13} \mathrm{C}-T_{1}$ data to be $4.0 \AA$. The transverse relaxation times measured by ${ }^{1} \mathrm{H}-\mathrm{NMR}$ indicate a partial flow of electron spin from the $\mathrm{Cu}^{2+}$ of $\mathrm{Cu}$-chln to the protons of FMN; this suggests that a charge-transfer complex is formed between $\mathrm{Cu}$ chln and FMN. 